\title{
ANALISIS PENERIMAAN RETIBUSI PARKIR KOTA MANADO TAHUN 2008-2012
}

\author{
Oleh: \\ Edward Ricardo Go \\ Jullie Sondakh \\ Heince Wokas \\ Fakultas Ekonomi dan Bisnis, Jurusan Akuntansi \\ Universitas Sam Ratulangi \\ email : edwardricardogo@yahoo.com
}

\begin{abstract}
ABSTRAK
Retribusi parkir merupakan salah satu sumber utama bagi Pendapatan Asli Daerah (PAD). Berlakukanya otonomi daerah di Indonesia, menjadikan retribusi parkir sebagai salah satu sumber penerimaan daerah. Penelititan ini dilakukan di Kantor Dinas Perhubungan (DISHUB) Kota Manado, Unit Pelaksana Teknis (UPT) Perparkiran yang bertanggung jawab dalam pengelolaan retribusi parkir. Penelitian ini bertujuan menganalisis perkembangan penerimaan retribusi parkir, meramalkan realisasi penerimaan retribusi parkir pada tahun 2016-2020, dan memberikan gagasan/wacana untuk meningkatkan efektivitas retribusi parkir dikemudian hari. Metode analisis yang digunakan adalah metode analisis deskriptif. Berdasarkan hasil penelitian ini menunjukkan bahwa UPT Perparkiran Dishub Kota Manado telah memenuhi target realisasi penerimaan retribusi parkir oleh Pemkot Manado dengan maksimal dan efektif. Setelah dilakukan analisis efektivitas dapat disimpulkan, realisasi penerimaan retribusi parkir terus mengalami peningkatan mulai dari $61,20 \%$ pada tahun 2008 hingga mencapai $111,46 \%$ pada tahun 2012. Berdasarkan peramalan besarnya realisasi penerimaan retribusi parkir pada tahun 2016-2020, dapat disimpulkan bahwa realisasi penerimaan retribusi parkir terus mengalami peningkatan, dari tahun 2012-2016 meningkat sebesar 385,83\%, hingga mencapai 907,7\% pada tahun 2020. Berdasarkan peramalan tersebut, untuk meningkatkan efektivitas penerimaan retribusi parkir, UPT Perparkiran Dishub Kota Manado disarankan melakukan perbaikan mulai dari evaluasi kebijakan tarif, efisiensi dan efektivitas SDM terhadap pengawasan rutin di TKP, dan perbaikan sumber daya atau menggunakan sistem komputerisasi untuk meminimalisasi penyelewengan.
\end{abstract}

Kata kunci : realisasi efektivitas penerimaan retribusi parkir, analisis trend.

\begin{abstract}
Parking retribution is one main source for Regional Original Revenue (PAD). The employment of regional autonomy in Indonesia makes parking retribution as one source of regional revenues. This research was done in Transportation Institution Office (DISHUB) Manado City and Parking Technical Executing Units (UPT) that responsible in handling parking retribution management. This research aims to analyze the development of parking retribution revenues, to forecast the realization of parking retribution effectiveness from 2016 until 2020, and to give insight for improving the parking retribution effectiveness in the future. The used analysis method is descriptive analysis method. Based on this research results, it is shown that UPT DISHUB Kota Manado have met the realization target of parking retribution revenues by Regional Government Manado, excellently and effectively. After the effectiveness analysis has been done, it can be concluded that the realization of parking retribution revenues is still increasing, starting from $61.20 \%$ at 2008 , until reaching 111.46 at 2012. Based on the forecasting of parking retribution revenues amount from 2016 until 20120, it is simplified that the realization of parking retribution is always increasing, between 2012-2016, it has increased up to $385.83 \%$ until reach $361.04 \%$ at 2020 . Based on those forecasting, for improving the effectiveness of this revenues, it is suggested to parking UPT for conducting enhancement, start from fee policy evaluation, HR efficiency and effectiveness to routine monitoring in TKP, and Natural Resources improvement or using computerized system to minimize indiscipline.
\end{abstract}

Keywords $\quad$ : realization of parking retribution effectiveness, trends analysis. 


\section{Latar Belakang}

\section{PENDAHULUAN}

Negara Republik Indonesia adalah negara hukum berdasarkan Pancasila dan Undang-Undang Dasar 1945 yang menjunjung tinggi hak dan kewajiban setiap masyarakat. Oleh karena itu negara menempatkan perpajakan sebagai perwujudan salah satu kewajiban kenegaraan dalam rangka kegotong royongan nasional sebagai peran serta aktif masyarakat dalam membiayai pembangunan. Pembiayaan pemerintah daerah dalam melaksanakan tugas pemerintahan dan pembangunaan senantiasa memerlukan sumber penerimaan yang dapat diandalkan. Kebutuhan ini semakin dirasakan oleh daerah terutama sejak diberlakukannya otonomi daerah di Indonesia, yaitu mulai tanggal 1 Januari 2001. Dengan adanya otonomi, daerah dipacu untuk dapat berkreasi mencari sumber penerimaan daerah yang dapat mendukung pembiayaan pengeluaran daerah.

Sektor pajak merupakan pilihan yang sangat tepat, selain karena jumlahnya yang relatif stabil tetapi juga merupakan cerminan partisipasi aktif masyarakat dalam membiayai pembangunan. Salah satu sumber pendapatan daerah yang dapat digali dalam rangka peningkatan PAD adalah retribusi daerah. Dari berbagai alternatif penerimaan Daerah, Undang-undang tentang penerimaan daerah dan juga tentang Perimbangan Keuangan antara Pemerintahan Pusat dan Daerah, menetapkan Pajak dan Retribusi Daerah sebagai sumber Pendapatan Asli Daerah ( PAD ) bersumber dari dalam Daerah itu sendiri. Sektor pajak sebagai salah satu sumber penerimaan negara yang sangat potensial.

Penetapan Undang-Undang di atas, menjadikan sektor pajak sebagai salah satu sumber penerimaan negara yang sangat potensial. Berdasarkan Undang-Undang tentang Pajak Daerah dan Retribusi Daerah, maka Pemerintah Kota Manado dalam hal ini Dinas Perhubungan Kota Manado bagian Unit Pelaksana Teknis Perparkiran menjadikan retribusi parkir sebagai salah satu sumber penerimaan yang berasal dari dalam daerah dan dapat dikembangkan sesuai dengan kondisi masing-masing daerah.

Seiring dengan meningkatnya aktivitas sosial ekonomi masyarakat di suatu daerah mengakibatkan peningkatan pada jumlah kendaraan yang digunakan masyarakat. Hal ini tentunya akan mengakibatkan meningkatnya permintaan akan lahan-lahan parkir, dan akhirnya mampu meningkatkan PAD Kota Manado melalui Retribusi Parkir. Pelayanan dalam bentuk penyediaan fasilitas parkir oleh pemerintah terdiri dari parkir di badan jalan (on street parking) atau biasa disebut parkir Tepi Jalan Umum (TJU) dan Parkir di luar badan jalan (off street parking) atau biasa disebut Tempat Khusus Parkir (TKP).

Berdasarkan fenomena dan potensi penerimaan dari retribusi parkir akan semakin besar, seiring dengan meningkatnya aktivitas sosial ekonomi masyarakat di suatu daerah mengakibatkan peningkatan pada jumlah kendaraan yang digunakan masyarakat. Hal ini tentunya akan mengakibatkan meningkatnya permintaan akan lahan-lahan parkir, dan akhirnya mampu meningkatkan PAD Kota Manado melalui Retribusi Parkir. Namun kondisi ini tidak sejalan dengan kondisi realisasi penerimaan retribusi parkir di Kota Manado. Hal ini disebabkan karena kontroversi yang sering terjadi dititik-titik parkir Kota Manado yang berada dititik pusat perekonomian Kota Manado, dimana masih kurangnya sumber daya yang disediakan oleh pihak Dishub, antara lain belum dibuatkan sistem komputerisasi yang canggih, pengaturan tata letak parkir, juru parkir yang belum memadai

\section{Tujuan Penelitian}

Tujuan penelitian ini adalah untuk menganalisis efektivitas penerimaan retribusi parkir, mengukur penerimaan retribusi parkir yang akan direalisasi pada tahun 2016-2020, dan mengidentifikasi serta memberikan gagasan/wacana untuk meningkatkan efektivitas retribusi parkir pada UPT Perparkiran Dinas Perhubungan di Kota Manado.

\section{Pengertian Akuntansi}

\section{TINJAUAN PUSTAKA}

Akuntansi menurut Wygandt et al, (2011: 4) adalah "In total, accounting involves the entire process of identifying, recording, and communicating economic event."

"Akuntansi bisa didefinisikan secara tepat dengan menjelaskan tiga karakteristik penting dari akuntansi: pengidentifikasian, pengukuran, dan pengkomunikasian informasi keuangan tentang entitas ekonomi kepada pemakai yang berkepentingan."

\section{Perpajakan}

Definisi atau pengertian pajak menurut Soemitro dikutip oleh Madiasmo (2009), pajak adalah iuran rakyat kepada kas negara berdasarkan undang-undang (yang dapat dipaksakan) dengan tiada mendapat jasa 
timbal (kontraprestasi) yang langsung dapat ditunjukkan dan yang digunakan untuk membayar pengeluaran umum. Menurut Feldmann, pajak adalah prestasi yang dipaksakan sepihak oleh terutang kepada penguasa, (menurut norma-norma yang ditetapkannya secara umum), tanpa adanya kontra-prestasi, dan semata-mata digunakan untuk menutup pengeluaran-pengeluaran umum. (Ilyas dan Burton, 2011:6).

Tarif pajak digunakan dalam perhitungan besarnya pajak terutang. Dengan kata lain, tarif pajak merupakan tarif yang digunakan untuk menentukan besarnya pajak yang harus dibayar (Waluyo, 2011: 18).

\section{Pendapatan Asli Daerah (PAD)}

Pendapatan Asli Daerah (PAD) menurut Siahaan (2010), yaitu penerimaan yang diperoleh daerah dari sumber-sumber dalam wilayahnya sendiri yang dipungut berdasarkan peraturan daerah seseuai dengan peraturan perundang-undang yang berlaku.

\section{Pajak Daerah dan Retribusi Daerah}

Pajak Daerah adalah iuran wajib yang dilkukan oleh daerah kepada orang pribadi atau badan tanpa imbalan langsung yang seimbang, yang dapat dipaksakan berdasarkan peraturan perundang-undang yang berlaku, yang digunakan untuk membiayai penyelenggaraan pemerintahan daerah dan pembangunan daerah (Siahaan, 2010: 9). Sedangkan Menurut UU No.28 Tahun 2009 Bab I tentang Ketentuan Umum Pasal 1 nomor 64 "Retribusi Daerah, yang selanjutnya disebut Retribusi, adalah pungutan Daerah sebagai pembayaran atas jasa atau pemeberian ijin tertentu yang khusus disediakan dan/atau diberikan oleh Pemerintah Daerah untuk kepentingan orang pribadi atau badan."

\section{Retribusi Parkir}

Dalam pengelolaan parkir di Kota Manado, Dinas Perhubungan (DISHUB) Unit Pelaksana Teknis (UPT) Perparkiran yang mengelolah retribusi parkir baik pada parkir di badan jalan (on street parking) atau biasa disebut parkir Tepi Jalan Umum (TJU) dan Parkir di luar badan jalan (off street parking) atau biasa disebut Tempat Khusus Parkir (TKP). Retribusi parkir merupakan salah satu sumber PAD yang berasal dari daerah itu sendiri, sehinggasStrategi merupakan rencana yang disatukan, menyeluruh dan terpadu yang berkaitan dengan keunggulan strategi. Keunggulan strategi dirancang sesuai dengan tantangan lingkungan sehingga tujuan utama dapat dicapai melalui pelaksanaan yang tepat oleh daerah. Dalam upaya meningkatkan kontribusi retribusi daerah terhadap PAD Pemerintah Daerah harus mampu merumuskan perencanaan strategis terkait dengan peningkatan penerimaan retribusi daerah.

\section{Definisi Efektivitas}

Penelitian kepustakaan yang ada mengenai teori efektivitas memperlihatkan keanekaragaman dalam hal indikator penilaian tingkat efektivitas suatu hal. Hal ini terkadang mempersulit penelaahan terhadap suatu penelitian yang melibatkan teori efektivitas, namun secara umum, efektivitas suatu hal diartikan sebagai keberhasilan dalam pencapaian target atau tujuan yang telah ditetapkan.

Efektivitas memiliki beragam jenis, salah satunya adalah efektivitas organisasi. Sama halnya dengan teori efektivitas secara umum, para ahli pun memiliki beragam pandangan terkait dengan konsep efektivitas organisasi. Efektivitas organisasi adalah tingkat keberhasilan pencapaian tujuan organisasi (target) atau dengan rumus $\mathrm{E}=\mathrm{R} / \mathrm{T}$. E:Efektivitas, R:Realisasi, T:Target. $\mathrm{R}$ adalah proses dalam hal ini proses produksi, dan setiap proses terdiri dari input, throughput dan output.

Berdasarkan teori tersebut, efektivitas merupakan penilaian terhadap hubungan target yang direncanakan dengan realisasi yang dicapai. Dengan adanya target yang diberikan maka tentunya ada usaha yang akan dilakukan oleh suatu lembaga atau perusahaan agar dalam menjalankan organisasinya terdapat tujuan yang jelas sehingga target tersebut dapat direalisasi dengan sebaik-baiknya ke suatu titik yang bisa dikatakan efektif.

\section{Analisis Trend}

Analisis trend merupakan suatu metode analisis yang ditujukan untuk melakukan suatu estimasi atau peramalan pada masa yang akan datang. Untuk melakukan peramalan dengan baik maka dibutuhkan berbagai macam informasi (data) yang cukup banyak dan diamati dalam periode waktu yang relatif cukup panjang, sehingga dari hasil analisis tersebut dapat diketahui sampai berapa besar fluktuasi yang terjadi dan faktor-faktor apa saja yang mempengaruhi terhadap perubahan tersebut.

Secara teoristis, dalam analisis time series yang paling menentukan adalah kualitas atau keakuratan dari informasi atau data-data yang diperoleh serta waktu atau periode dari data-data tersebut dikumpulkan. Jika data 
yang dikumpulkan tersebut semakin banyak maka semakin baik pula estimasi atau peramalan yang diperoleh.

Sebaliknya, jika data yang dikumpulkan semakin sedikit maka hasil estimasi atau peramalannya akan semakin jelek.

Metode yang digunakan untuk analisis time series adalah :

1. Metode Semi Rata-rata (semi average method)

Dalam metode ini data dibagi menjadi 2 bagian secara rata (K1 dan $\mathrm{K} 2)$, dengan persamaan linear

$\mathrm{Y}=\mathrm{a}+\mathrm{bX}$

$\mathrm{a} 1=\mathrm{K} 1$ untuk kelompok 1

$\mathrm{a} 2=\mathrm{K} 2$ untuk kelompok 2

$\mathrm{b}=\mathrm{k} 2-\mathrm{k} 1 /$ th dsr $2-$ th dsr 1

2. Metode Kuadrat Terkecil (least square method)

Dalam metode ini data juga dibagi dalam 2 kelompok yakni kelompok data ganjil dan genap, dengan persamaan linear $\mathrm{Y}=\mathrm{a}+\mathrm{bX}$

$\mathrm{a}=\Sigma \mathrm{Y}$

$\mathrm{b}=\Sigma \mathrm{XY}$

3. Metode Trend Kuadratis (quadratic trend method)

Dalam metode ini keseluruhan data diukur untuk menemukan trend dari suatu deret waktu,dengan persamaan non linear $\mathrm{Y}=\mathrm{a}+\mathrm{bX}+\mathrm{cX}$

Untuk mencari koefisien $\mathrm{a}, \mathrm{b}$ dan $\mathrm{c}$ digunakan rumus :

$$
a=\frac{\left(\sum \mathrm{Y}\right)\left(\sum \mathrm{X}^{4}\right)-\left(\sum \mathrm{X}^{2} \mathrm{Y}\right)\left(\sum \mathrm{X}^{2}\right)}{n\left(\sum \mathrm{X}^{4}\right)-\left(\sum \mathrm{X}^{2}\right)^{2}} \quad b=\frac{\sum X Y}{\sum X^{2}} \quad c=\frac{n\left(\sum X^{2} Y\right)-\left(\sum X^{2}\right)\left(\sum Y\right)}{n\left(\sum X^{4}\right)-\left(\sum \mathrm{X}^{2}\right)^{2}}
$$

4. $\quad$ Metode Trend Eksponensial (exponential trend method)

Dalam metode ini persamaan $\mathrm{Y}=\mathrm{a}(1+\mathrm{b}), \mathrm{LnY}=\operatorname{Ln} \mathrm{a}+\mathrm{X} \operatorname{Ln}(1+\mathrm{b})$

Untuk mencari koefisien $a$ dan $b$ :

$\mathrm{a}=\operatorname{anti} \operatorname{Ln}\left(\sum \operatorname{Ln} \mathrm{Y}\right) / \mathrm{n}$

$\mathrm{b}=\operatorname{anti} \operatorname{Ln}\left(\sum \operatorname{Ln} \mathrm{Y}\right)-1 \sum(\mathrm{X})$

Penelitian Terdahulu

Tabel 1. Penelitian Terdahulu

\begin{tabular}{|c|c|c|c|c|}
\hline Peneliti & Judul & Hasil Penelitian & Persamaan & Perbedaan \\
\hline Yunus (2012) & $\begin{array}{l}\text { Pengelolaan Retribusi } \\
\text { Parkir di Kota Makassar } \\
\text { (Studi Kasus di } \\
\text { Perusahaan Daerah } \\
\text { Parkir Makassar Raya) }\end{array}$ & $\begin{array}{l}\text { Hasil penelitian ini menunjukkan } \\
\text { bahwa perencanaan dalam hal ini } \\
\text { penentuan target retribusi parkir } \\
\text { pertahunnya masih belum efektif } \\
\text { karena tidak didukung oleh data- } \\
\text { data yang akurat mengenai } \\
\text { kawasan-kawasan parkir liar yang } \\
\text { dimanfaatkan orang-orang untuk } \\
\text { meraup keuntungan. }\end{array}$ & $\begin{array}{l}\text { Letak kesamaan } \\
\text { dengan penelitian } \\
\text { ini adalah } \\
\text { pembahasannya } \\
\text { mengenai } \\
\text { pengelolaan } \\
\text { penerimaan } \\
\text { retribusi parkir }\end{array}$ & $\begin{array}{l}\text { Dalam penelititan } \\
\text { ini membahas } \\
\text { tingkat penerimaan } \\
\text { retribusi parkir } \\
\text { namun pada objek } \\
\text { yang berbeda }\end{array}$ \\
\hline Rumagit (2011) & $\begin{array}{lr}\text { Analisis Pajak } & \text { Daerah } \\
\text { dan Retribusi } & \text { Daerah } \\
\text { Dalam } & \text { Struktur } \\
\text { Pendapatan Asli } & \text { Daerah } \\
\text { (PAD) Di Kota Manado }\end{array}$ & $\begin{array}{l}\text { Hasil penelitian ini menunjukkan } \\
\text { bahwa Pendapatan Asli Daerah } \\
\text { (PAD) Kota Manado sangat } \\
\text { bergantung pada penerimaan dari } \\
\text { pajak daerah dan retribusi daerah. }\end{array}$ & $\begin{array}{lr}\text { Letak } & \text { kesamaan } \\
\text { dengan } & \text { penelitian } \\
\text { ini } & \text { adalah } \\
\text { pembahasannya } \\
\text { mengenai } & \text { Retribusi } \\
\text { Daerah. } & \\
\end{array}$ & \begin{tabular}{lr}
\multicolumn{2}{l}{ Perbedaannya, } \\
objeknya & hanya \\
membahas & \\
Retribusi & Tempat \\
Khusus & Parkir \\
(TKP). & \\
\end{tabular} \\
\hline Hastuti (2008) & $\begin{array}{lr}\text { Strategi } & \text { Peningkatan } \\
\text { Penerimaan Retribusi } \\
\text { Tempat Khusus Parkir } \\
\text { (TKP) Kabupaten Bogor. }\end{array}$ & $\begin{array}{l}\text { Hasil penelitian ini menunjukkan } \\
\text { bahwa penyelenggaraan dan } \\
\text { pengelolaan oleh swasta lebih } \\
\text { efisien dari pada penyelenggaran } \\
\text { dan pengelolaan secara swakelola }\end{array}$ & $\begin{array}{l}\text { Penelitian ini } \\
\text { pembahasannya } \\
\text { mengenai } \\
\text { penerimaan } \\
\text { retribusi parkir }\end{array}$ & \begin{tabular}{lr}
\multicolumn{2}{l}{ Perbedaannya, } \\
objeknya hanya \\
membahas \\
Retribusi \\
$\begin{array}{l}\text { Khusus } \\
\text { (TKP). }\end{array}$ \\
\end{tabular} \\
\hline
\end{tabular}




\section{Jenis Penelitian}

\section{METODE PENELITIAN}

Penelitian ini berbentuk analisis deskriptif yaitu suatu metode yang dilakukan dengan cara mengumpulkan, menyajikan, serta menganalisis data sehingga diperoleh gambaran yang cukup jelas tentang masalah yang dihadapi, kemudian ditarik suatu kesimpulan mengenai perhitungan, pencatatan, dan pelaporan.

\section{Jenis dan Sumber Data}

Data adalah sekumpulan informasi yang diperlukan untuk pengambilan keputusan (Kuncoro, 2004). Data merupakan keterangan-keterangan yang diperoleh dari suatu penelitian yang dapat digunakan untuk menganalisa permasalahan yang dihadapi dan selanjutnya untuk mencari alternatif yang sesuai. Data dapat diklasifikasikan menjadi dua jenis yaitu data kuantitatif dan data kualitatif.

Data yang dibutuhkan dalam penelitian ini adalah data kualitatif berupa Peraturan Daerah Tentang Retribusi Jasa Usaha dan data kuantitatif berupa Laporan Rekapitulasi Penyetoran Retribusi PAD Perparkiran Dinaas Perhubungan Kota Manado periode 2008-2012.

\section{Sampel dan Populasi}

Populasi adalah suatu sebaran atau himpunan seluruh elemen sejenis dari suatu objek penelitian, yang diharapkan oleh peneliti untuk dipelajari dan kemudian ditarik kesimpulannya (Soeparno, 2009: 7). Dalam penelitian ini tidak menggunakan himpunan elemen atau populasi.

Sampel dalam statistik diartikan sebagai kelompok elemen yang menjadi bagian dari suatu populasi (Soeparno, 2009: 8). Dalam penelitian ini sampel yang digunakan adalah Laporan Rekapitulasi Penyetoran Retribusi PAD Perparkiran Dishub Kota Manado Tahun 2008-2012.

\section{Metode Analisis Data}

Analisis data adalah proses penyederhanaan data ke dalam bentuk yang lebih mudah dibaca dan diinterpretasikan. Metode analisis yang digunakan dalam penelitian ini adalah analisis deskriptif yaitu suatu metode yang dilakukan dengan cara mengumpulkan, menyajikan, serta menganalisis data sehingga diperoleh gambaran yang cukup jelas tentang masalah yang dihadapi, kemudian ditarik suatu kesimpulan mengenai perhitungan, pencatatan, dan pelaporan.

Dalam hal ini analisis yang akan digunakan untuk mendukung penelitian ini dengan menggunakan Teori Efektivitas $=$ Realisasi $/$ Target, dimana Efektivitas realisasi penerimaan retribusi parkir diukur dengan Realisasi retribusi parkir dibagi dengan Target penerimaan retribusi parkir yang langsung diberikan oleh Pemerintah Kota Manado.

Analisis Trend atau peramalan tingkat penerimaan realisasi retribusi parkir berdasarkan laporan rekapitulasi Retribusi PAD Perparkiran Dishub Kota Manado dalam kurun waktu 5 tahun terakhir (2008-2012), menjadi bahan uji analisis.

Dengan Persamaan Kuadratisnya : $\mathrm{Y}=\mathrm{a}+\mathrm{bX}+\mathrm{cX}$

Untuk mencari koefisien $\mathrm{a}, \mathrm{b}$ dan $\mathrm{c}$ digunakan rumus :

$$
b=\frac{\sum X Y}{\sum X^{2}} \quad c=\frac{n\left(\sum X^{2} Y\right)-\left(\sum X^{2}\right)\left(\sum Y\right)}{n\left(\sum X^{4}\right)-\left(\Sigma X^{2}\right)^{2}}
$$

Dengan mencari nilai koefisien a,b dan c dapat diramalkan Realisasi Retribusi Parkir pada beberapa tahun ke depan sebagai peramalan target dimasa yang akan datang. Dalam hal ini diambil tahun 2016-2020 sebagai tahun yang akan kita uji peramalan realisasi retribusi parkir

Dengan menggunakan analisis tersebut kita bisa melihat efektivitas penerimaan retribusi tempat khusus parkir dan menjadikannya sebagai bahan evaluasi agar kedepannya kita bisa memberikan gagasan atau wacana kepada pihak UPT Perparkiran Dishub Kota Manado mengenai fenomena yang akan dibahas.

\section{Hasil Penelitian}

\section{HASIL PENELITIAN DAN PEMBAHASAN}

Dalam rangka otonomi daerah, Pemkot Manado telah melakukan perubahan status desa menjadi kelurahan, melalui Perda No.4 dan 5 tahun 2005 sehingga jumlah kelurahan menjadi 87 kelurahan. Seiring dengan adanya pemekaran wilayah kecamatan, mengakibatkan jumlah kecamatan bertambah menjadi 9 kecamatan. 
Tabel 2 Luas Kota Manado Menurut Kecamatan Tahun 2010

\begin{tabular}{|l|l|l|}
\hline Kecamatan & Luas $(\mathbf{K m 2})$ & $\mathbf{\%}$ \\
\hline Malalayang & 17,12 & 10,88 \\
Sario & 1,75 & 1,11 \\
Wanea & 7,85 & 4,99 \\
Wenang & 3,64 & 2,31 \\
Tikala & 15,12 & 9,61 \\
Mapanget & 58,21 & 37,01 \\
Singkil & 4,68 & 2,97 \\
Tuminting & 4,31 & 2,74 \\
Bunaken & 44,58 & 28,35 \\
\hline JUMLAH & 157,26 & 100 \\
\hline
\end{tabular}

(Sumber: Badan Pusat Statistik Kota Manado 2010)

Penelitian ini dilakukan pada Dinas Perhubungan Kota Manado khususnya bagian Unit Pelaksana Teknis (UPT) Perparkiran yang mengelola Retribusi Parkir baik pada parkir Tepi Jalan Umum (TJU) yakni parkir di badan jalan (on street parking), dan Tempat Khusus Parkir (TKP) yakni parkir di luar badan jalan (off street parking). Dilihat dari keberadaan TKP dan TJU dalam ruang lingkup perparkiran, maka Dinas Perhubungan Kota Manado khususnya UPT Perparkiran diberikan kewenangan untuk mengelolah dan merealisasi target yang setiap tahunnya diberikan oleh pihak Pemerintah Kota Manado.

Dinas Perhubungan Kota Manado melalui Peraturan Walikota Manado nomor 16 Tahun 2009 tentang Unit Pelaksana Teknis pada Dinas Perhubungan Kota Manado, memutuskan pembentukan Unit Pelaksana Teknis (UPT) yang meliputi:

a. Unit Pelaksana Teknis Perparkiran

b. Unit Pelaksana Teknis Terminal

c. Unit Pelaksana Teknis Pengujian Kendaraan Bermotor

Sedangkan perparkiran yang berada di wilayah ruko, mall, manado town square, ataupun disektor industri lainnya dikelola oleh Dinas Penadapatan Daerah (DISPENDA) dan tidak ada kaitannya dengan retribusi parkir yang akan dibahas dalam penelitian. Hasil penelitian menunjukkan bahwa realisasi penerimaan retribusi parkir dari tahun 2008-2012 mengalami peningkatan yang signifikan, dan baik bagi perkembangan retribusi daerah khususnya pendapatan asli daerah yang mengalami peningkatan.

Berdasarkan penggolongan tempat parkir tersebut, maka penerimaan retribusi parkir dan target realisasi dari penerimaan retribusi parkir oleh UPT Perparkiran, dapat kita lihat dalam tabel Laporan Rekapitulasi Penyetoran Retribusi Tempat Khusus Parkir (TKP) PAD Perparkiran Dishub Kota Manado yang menjadi data untuk dibahas dalam penelitian ini (tahun 2008-2012) berikut.

Tabel 3 Laporan Rekapitulasi Penyetoran Retribusi PAD Perparkiran Dishub Kota Manado tahun 20082012

\begin{tabular}{|c|c|c|c|c|}
\hline Tahun & Target & Ret.TJU & Ret.TKP & Jumlah \\
\hline 2008 & $\begin{array}{l}\text { Retribusi TJU Rp 42.650.000,- } \\
\text { Retribusi TKP Rp 812.400.000,- }\end{array}$ & & Rp 474.527.800,- & Rp 523.284.800,- \\
\hline 2009 & $\begin{array}{l}\text { Retribusi TJU Rp 45.000.000,- } \\
\text { Retribusi TKP Rp 500.000.000,- }\end{array}$ & Rp 56.615.000,- & Rp 467.736.100,- & Rp 519.351.100,- \\
\hline 2010 & $\begin{array}{l}\text { Retribusi TJU Rp 76.400.000,- } \\
\text { Retribusi TKP Rp 802.500.000,- }\end{array}$ & Rp 57.055.500,- & Rp 618.152.700,- & Rp 675.208.200,- \\
\hline 2011 & $\begin{array}{l}\text { Retribusi TJU Rp 71,254,767,-- } \\
\text { Retribusi TKP Rp 915.000.000,- }\end{array}$ & Rp 58.155.000,- & Rp 904.976.925,- & Rp 963.131.925,- \\
\hline 2012 & $\begin{array}{l}\text { Retribusi TJU Rp 100.000.000,- } \\
\text { Retribusi TKP Rp 1.491.000.000,- }\end{array}$ & Rp 100.610.000,- & Rp 1.672.719.000,- & Rp 1.773.329.000,- \\
\hline Total & Rp 4.856.204.767,-. & Rp 320.192.500,-- & Rp 4.138.112.525,-- & Rp 4.458.305.025,- \\
\hline
\end{tabular}

(Sumber: UPT Perparkiran, 2013)

Berdasarkan tabel 3, Data Laporan Rekapitulasi Penyetoran Retribusi PAD Perparkiran Dishub Kota Manado penerimaan realisasi retribusi parkir khususnya untuk tahun 2008-2012 adalah Rp 4.458.305.025,- dari total keseluruhan target realisasi penerimaan retribusi parkir yang diberikan oleh Pemerintah Kota Manado tahun 2008-2012 adalah Rp 4.856.204.767,-- 


\section{Penerapan Pungutan Retribusi Tempat Khusus Parkir}

Berdasarkan hasil penelitian dan observasi, terdapat beberapa hal yang kurang sesuai dengan peraturan daerah serta peraturan pemungutan pajak yang ditetapkan oleh UPT Perparkiran. Beberapa contoh pelanggaran yang sering terjadi antara lain, kendaraan roda dua yang lalu lalang melewati TKP di Taman Kesatuan Bangsa, hampir semuanya tidak membayar retribusi sebagaimana jelas tertera dalam Perda tarif kendaran roda dua 3 jam pertama sebesar Rp 1.000,-. Hal ini tentu saja sering terjadi dan bisa dikatakan Perda yang telah ditetapkan oleh Pemerintah Kota dalam hal ini Walikota, diabaikan oleh masyarakat pengguna jalan dikarenakan tidak adanya sanksi bagi pelanggar peraturan daerah tersebut.

Sementara itu, tagihan karcis masuk kawasan Taman Kesatuan Bangsa (TKB) di pusat kota kembali menuai sorotan. Bahkan oleh sebagian kalangan, karcis untuk retribusi yang diberlakukan kepada setiap kendaraan yang memasuki kawasan tersebut, dinilai belum tepat. Sebab kebanyakan kendaraan yang hanya melewati kawasan TKB dan tidak menggunakan jasa parkir serta TKB merupakan akses jalan utama yang menghubungkan pusat kota. Hal ini tentunya sangat memberatkan sebagian besar masyarakat yang setiap harinya diharuskan untuk melewati area Tempat Khusus Parkir seperti kawasan TKB. Bahkan petugas juru parkir diarea TKB sering meminta lagi tagihan parkir di dalam kawasan, sehingga menimbulkan pungutan berganda.

\section{Penerapan Pungutan Retribusi Parkir Tepi Jalan Umum}

Berdasarkan observasi, penerapan pungutan retribusi parkir di Tepi Jalan Umum (TJU) belum memiliki peraturan dan kawasan yang jelas, sehingga kebanyakan juru parkir yang bertugas tidak profesional serta kebanyakan hanya warga daerah setempat yang bertugas. Berdasarkan hal tersebut, pemungutan retribusi parkir di TJU kurang maksimal dan masih menimbulkan kemacetan dibeberapa titik TJU.

Sementara itu, tarif parkir di TJU belum memiliki tarif yang jelas sehingga tarif yang dipungut dibeberapa lokasi berbeda-beda dan kejelasan aliran dana oleh juru parkir tidak jelas. Berdasarkan tata cara pemungutan retribusi parkir dan kelancaran lalu lintas sebaiknya UPT Perparkiran mengevaluasi serta memperbaiki tata cara pemungutan parkir, sehingga menciptakan kenyamanan bagi para pelaku jasa parkir di kota Manado serta meningkatkan pendapatan asli daerah.

\section{Pembahasan}

Tabel 4. Laporan Rekapitulasi Penyetoran Retribusi Parkir PAD Perparkiran Dishub Kota Manado tahun 2008-2012

\begin{tabular}{|l|l|l|l|}
\hline Tahun & Target & Realisasi & Presentase (\%) R/T \\
\hline 2008 & Rp855.050.000,-- & Rp 523.284.800,- & 61,20 \\
2009 & $\operatorname{Rp~545.000.000,-~}$ & Rp 519.351.100.,- & 95,29 \\
2010 & $\operatorname{Rp~878.900.000,-~}$ & Rp 675.208.200,- & 76,82 \\
2011 & $\operatorname{Rp~986.254.767,-~}$ & Rp 963.131.925,-- & 97,66 \\
2012 & $\operatorname{Rp~1.591.000.000,-~}$ & Rp 1.773.329.000,- & 111,46 \\
& & & \\
\hline Jumlah & $\operatorname{Rp~4.856.204.767,-.~}$ & Rp 4.458.305.025,-- & 91.53 \\
\hline
\end{tabular}

(Sumber: Olahan, 2013)

Berdasarkan tabel 4, Data Laporan Rekapitulasi Penyetoran Retribusi PAD Perparkiran Dinas Perhubungan Kota Manado penerimaan realisasi retribusi parkir khususnya untuk tahun 2008-2012 adalah Rp 4.458.305.025,- dari total keseluruhan target realisasi penerimaan retribusi parkir yang diberikan oleh Pemerintah Kota Manado tahun 2008-2012 adalah Rp 4.856.204.767,-.

Untuk mengukur apakah data tersebut bisa dikatakan efektif maka akan digunakan rumus Efektivitas =

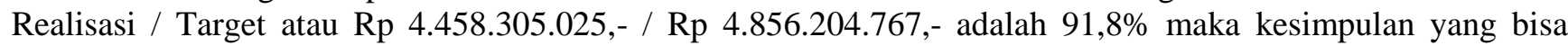
ditarik bahwa Dinas Perhubungan Kota Manado khususnya Unit Pelayanan Teknis (UPT) Perparkiran telah merealisasi target yang diberikan oleh Pemerintah Kota Manado dengan efektif. 
Gambar 1 Trend Efektivitas Realisasi Penerimaan Retribusi Parkir

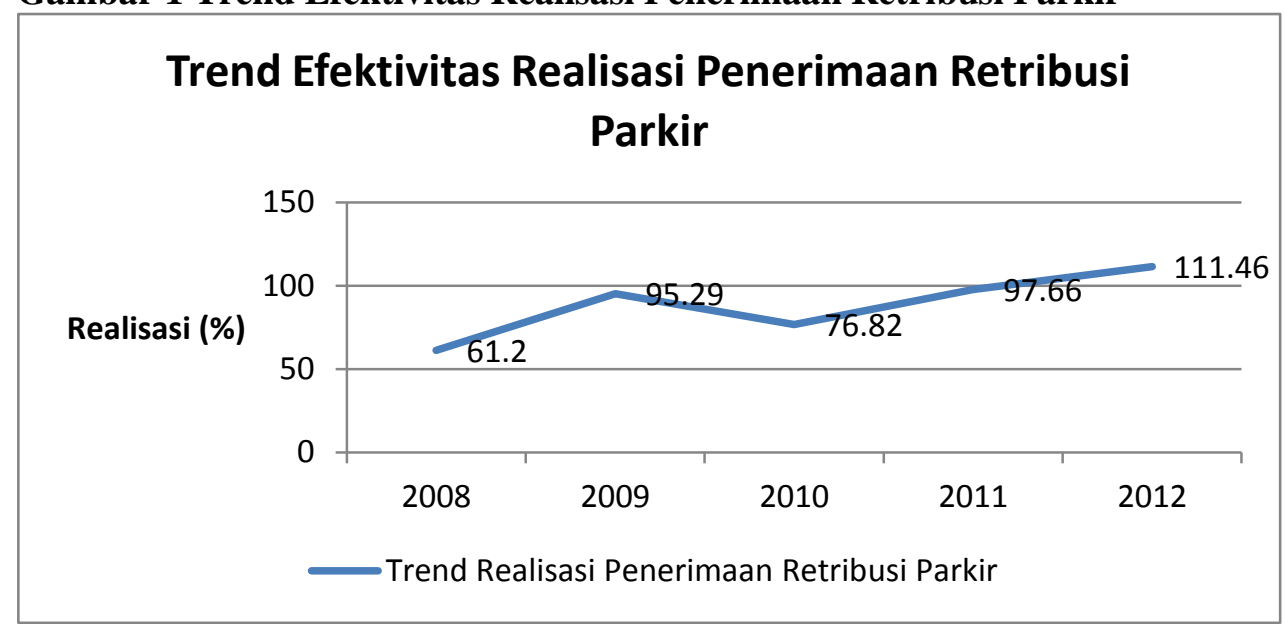

(Sumber: Olahan, 2013)

Berdasarkan Gambar 1, trend efektivitas realisasi penerimaan retribusi parkir, grafik nilai presentase realisasi pada tahun 2008 sebesar 61,20\%, pada tahun 2009 mengalami peningkatan yang cukup signifikan yakni nilai presentasinya sebesar 95,29\%, sedangkan pada tahun 2010 mengalami penurunan yang cukup signifikan dengan nilai presentase $76,82 \%$ dan pada tahun berikutnya yakni tahun 2011 kembali meningkat dinilai 97,66\%. Kemudian tahun 2012 mencapai nilai presentase tertinggi sebesar 111,46\%.

\section{Analisis Trend Kuadratis Realisasi Penerimaan Retribusi Parkir}

Berdasarkan data rekapitulasi penyetoran retibusi penyetoran retribusi PAD Perparkiran Dishub Kota Manado selama tahun 2008 sampai dengan tahun 2012, dapat diukur analisis trend atau peramalan ke depan realisasi penerimaan retribusi parkir yang dapat dicapai oleh UPT Perparkiran. Hasil analisis trend dapat dilihat dalam gambar tabel berikut ini.

Tabel 5 Analisis Trend Realisasi Penerimaan Retribusi Parkir UPT Perparkiran Dinas Perhubungan Kota Manado dari tahun 2008-2012

\begin{tabular}{|l|l|l|l|l|l|l|}
\hline Tahun & Realisasi (Y) & $\mathbf{X}$ & $\mathbf{X Y}$ & $\mathbf{X}^{\mathbf{2}}$ & $\mathbf{X}^{\mathbf{2}} \mathbf{Y}$ & \\
\hline 2008 & 523.284 .800 & -2 & -1.046 .569 .600 & 4 & 2.093 .139 .200 & 16 \\
2009 & 519.351 .100 & -1 & -519.351 .100 & 1 & 519.351 .100 & 1 \\
2010 & 675.208 .200 & 0 & 0 & 0 & 0 & 0 \\
2011 & 963.131 .925 & 1 & 963.131 .925 & 1 & 963.131 .925 & 1 \\
2012 & 1.773 .329 .000 & 2 & 3.546 .658 .000 & 4 & 7.093 .316 .000 & 16 \\
\hline Jumlah & 4.458 .305 .025 & & 2.943 .869 .225 & 10 & 10.668 .938 .225 & 34 \\
& & & & & & \\
\hline
\end{tabular}

(Sumber: Olahan, 2013)

Dengan Persamaan Kuadratisnya : $\mathrm{Y}=\mathrm{a}+\mathrm{bX}+\mathrm{cX}$

$$
a=\frac{\left(\sum \mathrm{Y}\right)\left(\sum \mathrm{X}^{4}\right)-\left(\sum \mathrm{X}^{2} \mathrm{Y}\right)\left(\sum \mathrm{X}^{2}\right)}{n\left(\sum \mathrm{X}^{4}\right)-\left(\sum \mathrm{X}^{2}\right)^{2}} \quad c=\frac{n\left(\sum X^{2} Y\right)-\left(\sum X^{2}\right)\left(\sum Y\right)}{n\left(\sum X^{4}\right)-\left(\sum \mathrm{X}^{2}\right)^{2}} \frac{\sum X Y}{\sum X^{2}}
$$

Dengan mencari nilai koefisien a,b dan c dapat diramalkan Realisasi Retribusi Parkir pada beberapa tahun ke depan sebagai peramalan target dimasa yang akan datang. Dalam hal ini diambil tahun 2016-2020 sebagai tahun yang akan kita uji peramalan realisasi retribusi parkir.

Penyelesaian:

$$
\begin{aligned}
a & =\frac{(4.138 .112 .525) \cdot(34)-(10.052 .700 .225) \cdot(10)}{5 .(34)-(10)^{2}} \\
& =\frac{40.168 .823 .600}{70} \\
& =573.840 .337,14 \\
b & =\frac{2.833 .623 .225}{10}
\end{aligned}
$$




$$
c=\frac{5(10.052 .700 .225)-(10) \cdot(4.138 .112 .525)}{5 .(34)-(10)^{2}}
$$

$=126.891 .083 .92$

Dengan menggunakan persamaan tersebut, dapat diramalkan Realisasi Retribusi Parkir UPT Perparkiran dari tahun 2016-2020.

Jadi pada tahun 2016 diperkirakan realisasi retribusi parkir bisa mencapai Rp 6.842.093.293,-

Jadi pada tahun 2017 diperkirakan realisasi retribusi parkir bisa mencapai Rp 8.775.039.706,72,-

Jadi pada tahun 2018 diperkirakan realisasi retribusi parkir bisa mencapai $\mathrm{Rp} 10.961 .768 .288,02,-$

Jadi pada tahun 2019 diperkirakan realisasi retribusi parkir bisa mencapai Rp 13.402.279.037,16,Jadi pada tahun 2020 diperkirakan realisasi retribusi parkir bisa mencapai Rp 16.096.571.954,14,-

Gambar 2 Trend Peramalan Realisasi Penerimaan Retribusi Parkir

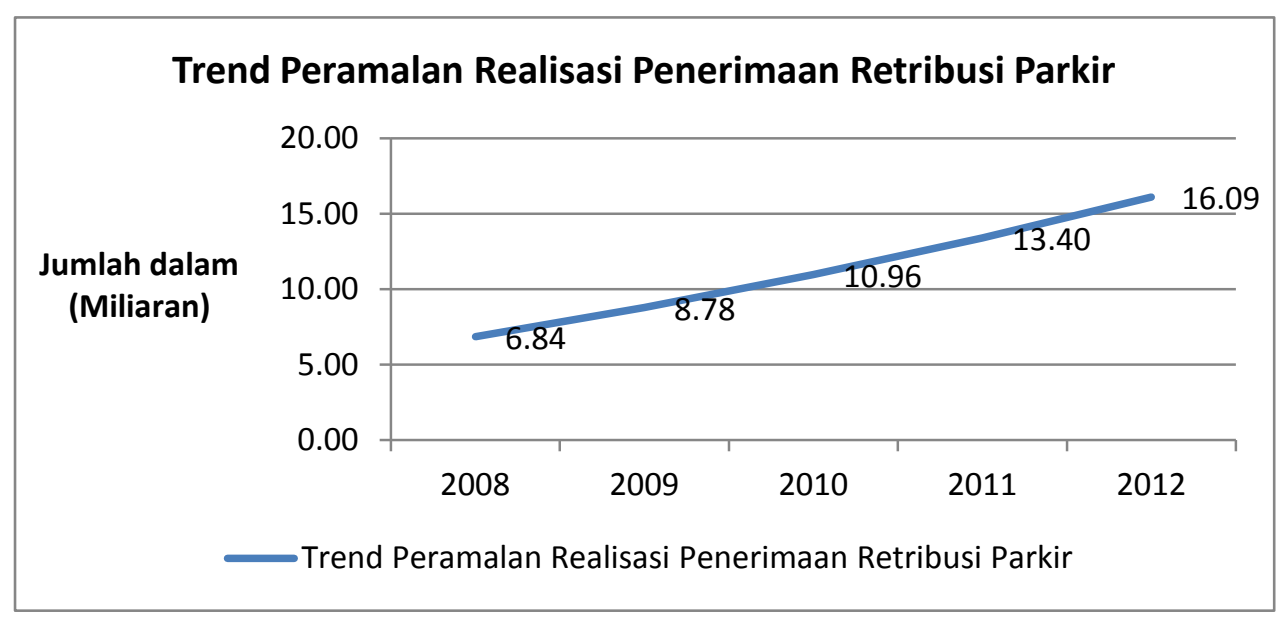

(Sumber : Olahan, 2013)

Menurut trend Gambar 2, dapat dlihat hasil tersebut realisasi penerimaan retribusi parkir di kota Manado terus mengalami peningkatan yang konsisten setiap tahun. Dengan perkembangan ini tentu sangat baik bagi perkembangan PAD Kota Manado dan tentu saja jalanan maupun lahan parkir harus ditata dan diatur dengan sebaik-baiknya agar realisasi penerimaan retribusi parkir akan semakin meningkat. Bila dilihat dari realisasi retribusi parkir pada tahun 2012, sebesar Rp 1.773.329.000,- mengalami peningkatan yang sangat signifikan pada angka 907,7\% pada tahun 2020, yakni sebesar Rp 16.096.571.954,14,--

Berdasarkan hasil peramalan tersebut, dapat menjadi acuan bagi pihak Pemerintah Kota Manado dalam pemberian target realisasi penerimaan retribusi parkir setiap tahunnya, sehingga dalam penentuan dan pelaksanaannya dilapangan pihak UPT Perparkiran dapat meningkatkan kinerjanya. Apabila mengacu pada teori efektivitas, pemberian target yang optimal dan dengan perhitungan yang baik, maka tentunya ada usaha yang akan dilakukan agar dalam menjalankan tugasnya terdapat tujuan yang jelas sehingga target tersebut dapat direalisasi dengan optimal dan bisa dikategorikan efektif.

Hasil analisis dari keseluruhan data menunjukkan, bahwa UPT Perparkiran Dishub Kota Manado telah merealisasi target dari Pemerintah Kota Manado dengan baik dan apabila setiap tahunnya target dari Pemerintah semakin meningkat maka akan sangat baik bagi perkembangan Pendapatan Asli Daerah (PAD) Kota Manado yang akan juga semakin meningkat. Kemudian pada tahun 2012 setelah terjadi pergantian Kepala UPT Perparkiran, nilai presentase realisasi retribusi parkir mencapai nilai tertinggi dan mencapai nilai presentasi sebesar $111,46 \%$.

Tentu dari hasil tersebut dan dengan sumber daya manusia (SDM) maupun sumber daya seperti sekarang, UPT Perparkiran Dishub Kota Manado telah merealisasi target dari Pemkot Manado dengan efektif. Sedangkan perbaikan SDM sangat diperlukan untuk memaksimalkan sumber penerimaan retribusi parkir, mulai dari profesionalisme juru parkir, tarif parkir TJU yang diatur dengan jelas sehingga tidak menimbulkan kebingungan bagi masyarakat. Sedangkan perbaikan sumber daya dimulai dengan menggunakan sistem komputerisasi yang 
lebih canggih, sehingga nilai presentasi diyakini dapat lebih ditingkatkan dan penyelewengan pemungutan retribusi parkir dan pemungutan ganda di dalam kawasan bisa diminimalisasi serta keadaan lalu lintas di Kota Manado akan semakin lebih baik.

\section{Kesimpulan}

\section{PENUTUP}

Berdasarkan penelitian yang dilakukan terhadap Unit Pelaksana Teknis Dishub Kota Manado, maka dapat dikemukakan beberapa hal yang dapat disimpulkan sebagai berikut :

1. UPT Perparkiran Dishub Kota Manado telah merealisasi target realisasi penerimaan retribusi parkir yang diberikan oleh Pemerintah Kota Manado secara maksimal dan efektif. Setelah dilakukan analisis efektivitas dapat disimpulkan bahwa realisasi penerimaan retribusi parkir terus mengalami peningkatan mulai dari 61,20 $\%$ pada tahun 2008 hingga mencapai 111,46 \% pada tahun 2012. Target yang diberikan oleh Pemerintah Kota Manado yang semakin meningkat setiap tahunnya sangat dan harus dibarengi dengan perbaikan sumber daya yang ada.

2. Target retribusi yang diberikan oleh Pemerintah Kota Manado cenderung belum menggunakan suatu metode yang tepat. Contohnya target TKP tahun $2008 \mathrm{Rp} 812.400 .000$,- tetapi tahun 2009 mengalami penurunan hingga Rp 500.000.000,- sehingga realisasi retribusi parkir masih mengalami fluktuasi yang belum beraturan atau naik turun. Kemudian setelah melakukan analisis trend atau peramalan pada tahun 2016-2020 diperkirakan realisasi retribusi parkir oleh UPT Dishub Kota Manado akan terus mengalami peningkatan mulai dari $\mathrm{Rp}$ 6.842.093.293,26,- pada tahun 2016 atau mengalami peningkatan dari $\mathrm{Rp}$ 1.773.329.000,pada tahun 2012 sebesar 385,83\%, hingga mencapai angka Rp 16.096.571.954,14,- pada tahun 2020 atau meningkat $907,7 \%$ dari tahun 2012.

3. Sementara itu, tarif parkir dan sistem pemungutan retribusi parkir belum memiliki tarif yang jelas dan tata cara pemungutan yang belum maksimal kejelasan aliran dana oleh juru parkir masih belum jelas. Berdasarkan tata cara pemungutan retribusi parkir dan kelancaran lalu lintas sebaiknya UPT Perparkiran Dishub Kota Manado mengevaluasi serta memperbaiki tata cara pemungutan parkir, sehingga menciptakan kenyamanan bagi para pelaku jasa parkir di kota Manado serta meningkatkan pendapatan asli daerah.

\section{Saran}

1. Berdasarkan teori efektivitas, pemberian target yang optimal dan dengan perhitungan yang baik, maka tentunya ada usaha yang akan dilakukan oleh suatu lembaga atau perusahaan agar dalam menjalankan organisasinya terdapat tujuan yang jelas sehingga target tersebut dapat direalisasi dengan sebaik-baiknya ke suatu titik yang bisa dikatakan efektif

2. Penulis menyarankan kepada pihak UPT Perparkiran Dishub Kota Manado untuk lebih berupaya meningkatkan realisasi penerimaan retribusi parkir terus ditingkatkan, mulai dari evaluasi kebijakan tarif, efisiensi dan efektivitas SDM pengelola, pengawasan pengelolaan TKP, komputerisasi, dan perbaikan sistem dalam melakukan pengawasan rutin untuk meminimalisasi penyelewengan uang retribusi.

3. Melihat keadaan jumlah kendaraan pribadi dan kendaraan umum yang semakin meningkat, sebaiknya pihak UPT Perparkiran Dishub Kota Manado melakukan penambahan jumlah lahan parkir yang baru agar perparkiran bisa lebih terkendali dan tidak menimbulkan kemacetan serta penambahan juru parkir yang memadai

\section{DAFTAR PUSTAKA}

Hastuti. 2008. Strategi Peningkatan Penerimaan Retribusi Tempat Khusus Parkir (TKP) Kabupaten Bogor. Tesis. Institut Pertanian Bogor. Bogor

Ilyas., Burton. 2011. Hukum Pajak. edisi 5. Salemba Empat. Jakarta

Kuncoro, Mudrajad. 2004. Metode Kuantitatif. Edisi Kedua. UPP AMP YKPN. Yogyakarta.

Mardiasmo. 2009. Perpajakan. edisi revisi 2009. Andi. Yogyakarta

Rumagit, Melanie. 2011. Analisis Pajak Daerah dan Retribusi Daerah Dalam Struktur Pendapatan Asli Daerah (PAD) di Kota Manado. Skripsi. Universitas Sam Ratulangi. Manado

Siahaan. 2010. Pajak Daerah dan Retribusi Daerah. edisi revisi 2010. PT RajaGrafindo Persada. Jakarta.

Soeparno. 2009. Analisis Forecasting dan Keputusan Manajemen. Salemba Empat. Jakarta 
UU RI No.28 Tahun 2009. Pajak Daerah dan Retribusi Daerah. SL Media. Jakarta

Waluyo. 2011. Perpajakan Indonesia. edisi 10 buku 1. Salemba Empat. Jakarta

Yunus, Sartika. 2012. Pengelolaaan Retribusi Parkir di Kota Makassar (Studi Kasus diPerusahaan Daerah Parkir Makassar Raya. Skripsi. Universitas Hasanuddin. Makassar

Weygandt., Kimmel., Kieso. 2011. Financial Accounting IFRS Edition. John Wiley \& Sons, Inc. USA 